\title{
Use of the spray chilling method to deliver hydrophobic components: physical characterization of microparticles
}

\author{
Utilização do método de spray chilling para veiculação de componentes hidrofóbicos: \\ caracterização física das micropartículas
}

\author{
Izabela Dutra ALVIM ${ }^{1 \star}$, Fabrizia da Silva de SOUZA ${ }^{1}$, Isabela Paes KOURY', \\ Thais JURT ${ }^{1}$, Fiorella Balardin Hellmeister DANTAS ${ }^{2}$
}

\begin{abstract}
Food industry has been developing products to meet the demands of increasing number of consumers who are concerned with their health and who seek food products that satisfy their needs. Therefore, the development of processed foods that contain functional components has become important for this industry. Microencapsulation can be used to reduce the effects of processing on functional components and preserve their bioactivity. The present study investigated the production of lipid microparticles containing phytosterols by spray chilling. The matrices comprised mixtures of stearic acid and hydrogenated vegetable fat, and the ratio of the matrix components to phytosterols was defined by an experimental design using the mean diameters of the microparticles as the response variable. The melting point of the matrices ranged from 44.5 and $53.4^{\circ} \mathrm{C}$. The process yield was melting point dependent; the particles that exhibited lower melting point had greater losses than those with higher melting point. The microparticles' mean diameters ranged from 13.8 and $32.2 \mu \mathrm{m}$ and were influenced by the amount of phytosterols and stearic acid. The microparticles exhibited spherical shape and typical polydispersity of atomized products. From a technological and practical (handling, yield, and agglomeration) points of view, lipid microparticles with higher melting point proved promising as phytosterol carriers.
\end{abstract}

Keywords: solid lipid microparticles; phytosterols; controlled release.

\section{Resumo}

A indústria alimentícia vem desenvolvendo produtos para atender a um crescente grupo de consumidores mais exigentes com a saúde que buscam alimentos que atendam suas necessidades. Criar alimentos processados contendo compostos funcionais torna-se, então, importante para essa indústria. Para reduzir efeitos do processamento sobre os compostos funcionais, pode se empregar a sua microencapsulação para proteção e manutenção da bioatividade. Nesse trabalho, estudou-se a obtenção de micropartículas lipídicas, contendo fitosteróis, por spray chilling. As matrizes constituíram-se de misturas de ácido esteárico e gordura vegetal hidrogenada e a proporções entre os componentes das matrizes e fitosteróis foram definidas em planejamento experimental com os diâmetros médios das micropartículas utilizados como resposta. Os ponto de amolecimento das matrizes apresentaram valores entre 44,5 e $53,4{ }^{\circ} \mathrm{C}$. O rendimento do processo foi dependente do PA, com matrizes de menores PA apresentando maiores perdas do que matrizes com maiores PA. Os diâmetros médios das amostras variaram entre 13,8 e 32,2 $\mu \mathrm{m}$ pelos efeitos da quantidade de ativo e da quantidade de ácido esteárico. As micropartículas apresentaram-se esféricas e com polidispersidade típica de amostras atomizadas. Do ponto de vista tecnológico e de aplicação (manuseio, rendimento, aglomeração), micropartículas lipídicas com maiores pontos de fusão mostraram-se mais promissoras como carreadoras de compostos hidrofóbicos.

Palavras-chave: micropartículas lipídicas sólidas; fitosteróis; liberação controlada.

\section{Introduction}

The development of new products by the food industry is associated with several factors, among which is the increasing number of more demanding consumers with wider access to information and seek food products to meet their needs (BRASIL..., 2010). The incorporation of compounds with functional properties into processed foods has thus become an important area of development and innovation in the food industry. Processing can affect the functional properties of these compounds, but these effects can be minimized through the use of microencapsulation as a strategy to protect and maintain their activity. Microencapsulation is based on the formation of a barrier (wall) around the substance of interest (active or core material) to control the interaction of this substance with the medium in which it will be added. This barrier can be created in many different ways which will exert a direct impact on the interaction between the active substance and the medium (processed food) (THIES, 1995; RÉ, 1998; CHAMBI et al., 2008; ALVIM; GROSSO, 2010).

Among the methods of microencapsulation, spray chilling represents an advantageous alternative to other

Center of Cereal and Chocolate Technology - CEREAL CHOCOTEC, Institute of Food Technology - ITAL, CEP 13070-178, Campinas, SP, Brazil,

e-mail: izabela@ital.sp.gov.br

${ }^{2}$ Packaging Technology Center - CETEA, Institute of Food Technology - ITAL, CEP 13070-178, Campinas, SP, Brazil

${ }^{*}$ Corresponding author 
processes due to its mild processing conditions, good levels of retention of volatile components, and possible large-scale production. Microencapsulation by spray chilling is grounded on the atomization of lipid mixtures in liquid form (below the melting point of the lipids) containing the substance of interest in a chilled chamber. The fine droplets formed by atomization containing the core material become rigid when in contact with cold air in the atomizing chamber and form Solid Lipid Microparticles (SLM) (Figure 1). The fillings used can be hydrophilic or hydrophobic, in liquid or solid forms. The wall materials can be fats, waxes, or their blends with oils in order to modulate the melting point and the core material retention properties (CHAMBI et al., 2008; ILIĆ et al., 2009; PASSERINI et al., 2009).

Phytosterols (PT) are plant sterols with structure very similar to that of cholesterol, and their physiological action is based on the inhibition of intestinal cholesterol absorption, followed by the prevention of micelle formation, which may also be absorbed by the organism. Thus, the intake of phytosterols plays an important role in the reduction of blood cholesterol levels and the consequent prevention of diseases associated with hypercholesterolemia (BRUFAU; CANELA; RAFECAS, 2008; KRITCHEVSKYA; CHEN, 2005; JONES et al., 2003; WEINGÄRTNER; BÖHM; LAUFS, 2009). Phytosterols have been added to processed foods such as margarine and dairy products; however, their incorporation into other products processed under high heat and low humidity levels is still limited due to loss in functionality resulting from the deterioration caused by processing conditions (PIMENTA et al., 2009; HOVENKAMP et al., 2008; CERCACI et al., 2007).

Production of intact and stable SLM is the first step in the development of an efficient product; therefore, the present study

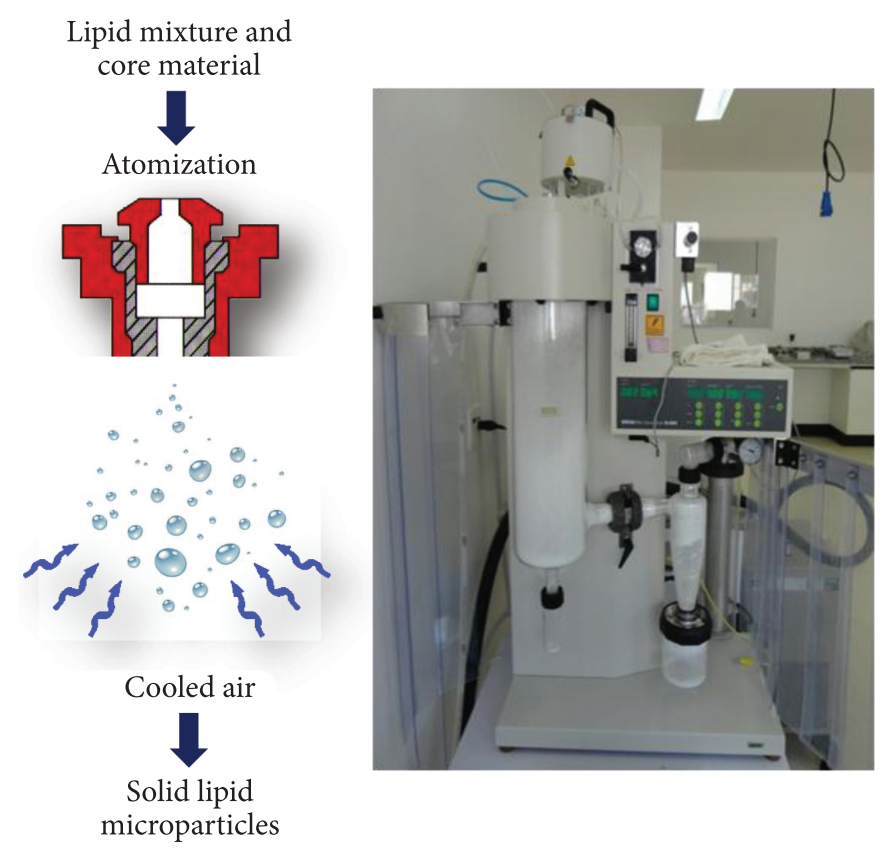

Figure 1. Scheme of spray chilling process and equipment used in SLP production. investigated the viability of using the spray chilling technique in the production of lipid microparticles containing phytosterols by assessing the structural integrity and morphological characteristics of these particles.

\section{Materials and methods}

\subsection{Production of Solid Lipid Microparticles (SLM)}

The wall material used was a lipid mixture of low trans hydrogenated vegetable fat (HVF) (Bunge, São Paulo, São Paulo, Brazil) and stearic acid (SA) (Vetec, Duque de Caxias, Rio de Janeiro, Brazil), and the core material was a phytosterol mixture (PT) (Vegapure, 95 FF, Cognis, São Paulo, São Paulo, Brazil with the following major componentes: brassicasterol, stigmasterol, campesterol and sistosterol, second product datasheet). The amounts and different proportions of each component were determined by a central composite rotatable design (CCRD).

The CCRD with 2 factors and 2 levels $\left(2^{2}\right)$ was used to perform the tests for the microencapsulation of phytosterols by the spray chilling method. The total number of experiments was 12 divided into 4 principal points, 4 axial points, and 4 central points. Two independent variables were considered: core content with respect to total solids $\left(\mathrm{x}_{1}\right)$ and stearic acid content with respect to total of lipid mixture $\left(\mathrm{x}_{2}\right)$. The response used to asses experimental design was the particle mean diameter $\left(\mathrm{Y}_{1}\right)$. The real and the coded levels of the independent variables are presented in Table 1.

To produce the SLM containing phytosterol, the mixtures of lipid components were heated at $70{ }^{\circ} \mathrm{C}$ until complete fusion, according to the experimental design. The content of phytosterol determined by the experimental design was added and mixed manually to the lipid mixture. The lipid mixtures and the core material, kept at $70{ }^{\circ} \mathrm{C}$, were then sprayed with a $0.7 \mathrm{~mm}$ two-fluid pressurized atomizer in a Büchi-B290 spray dryer with spray chilling module (Figure 1, Büchi, Uster, Switzerland). The atomizing air flow rate was $500-600 \mathrm{NL} / \mathrm{h}$, and the inlet temperature was cooled by a Büchi Dehumidifier B296 at $5 \pm 2{ }^{\circ} \mathrm{C}$ (Büchi, Uster, Switzerland). The samples of SLM produced were collected and stored at $-18{ }^{\circ} \mathrm{C}$ (adapted from LEONEL et al., 2010).

\subsection{Characterization of Solid Lipid Microparticles (SLM)}

The microparticles obtained from the formulations studied were characterized according to the following methods.

\section{Melting point of lipid mixtures}

The melting points of the lipid mixtures were determined by the open capillary tube method (Cc 3-25), according to the

Table 1. Real and coded levels of independent variables.

\begin{tabular}{ccccccc}
\hline $\begin{array}{c}\text { Independent } \\
\text { variables (\%) }\end{array}$ & $\begin{array}{c}\text { Coded } \\
\text { variables }\end{array}$ & -1.41 & -1 & 0 & +1 & +1.41 \\
\hline Phytosterols Content $^{\mathrm{a}}$ & $\mathrm{x}_{1}$ & 6 & 10 & 20 & 30 & 34 \\
Stearic Acid Content $^{\mathrm{b}}$ & $\mathrm{x}_{2}$ & 26 & 33 & 50 & 67 & 74 \\
\hline
\end{tabular}

acore content with respect to total solids; ${ }^{\mathrm{b}} \mathrm{SA}$ content with respect to total of lipid mixture. 
AOCS official method (AMERICAN..., 2005). Capillary tubes ( $1 \mathrm{~mm}$ inside diameter) were filled to a height of $10 \mathrm{~mm}$ with melted lipid mixture and cooled at $10{ }^{\circ} \mathrm{C}$ overnight. The cooled tubes were heated slowly, and the endpoint was determined by the physical movement of the fat column. Determinations were performed in 10 replicates.

\section{Mean size and size distribution of lipid microparticles}

Samples of each formulation were observed by Optical Microscopy (OM) (BX4, Olympus, Tokyo, Japan) using the objective of $100 \times$, and the images were acquired using a digital camera (Q-Color3, Olympus, Tokyo, Japan). The mean diameters (500 particles) were determined by the freeware software Scion Image (www.scioncorp.com) (ALVIM; GROSSO, 2010).

\section{Surface morphology}

Surface morphology of SLM was evaluated by optical microscopy and scanning electron microscopy (SEM). For the SEM analysis, the samples were fixed on aluminum stubs with double-sided copper adhesive tape and coated with a fine layer of gold using a sputter coater (SDC50, Bal-Tec, Balzers, Liechtenstein) for 4 coating cycles of 40 seconds each. The samples were subsequently examined using a scanning electron microscope (DSM 940A, Zeiss, Oberkocken, Germany) at an acceleration voltage of $10 \mathrm{kV}$ (LEONEL et al., 2010). The same procedure described to acquire images for the mean size and size distribution analysis, according to Alvim and Grosso (2010), was used for the OM images.

\subsection{Statistical analysis}

The Statistica 5.5 (StatSoft Inc., Tulsa, USA) software was used for the regression coefficient calculation and variance, response surfaces, and Pareto analysis. The statistical analyses were reported with $95 \%$ confidence intervals.

\section{Results and discussion}

The melting points of the lipid matrices used in this experiment exhibited increasing values (between 44.5 and $53.4^{\circ} \mathrm{C}$ ) with increased levels of stearic acid (Figure 2).

The mean diameters of the lipid microparticles containing phytosterols assessed as a response to the experimental design assays are described in Table 2. The mean diameters varied between 13.8 and $32.2 \mu \mathrm{m}$, and were thus within the range reported by the literature (SAVOLAINEN et al., 2002; LEONEL et al., 2010; CHAMBI et al., 2008).

In the assessment of the experimental design using the Pareto chart (Figure 3a), the mean diameters of the lipid microparticles containing phytosterols were significantly influenced by the amount of active substance used and the stearic acid content in the lipid matrix.

Variable amounts of stearic acid in the lipid mixture exhibited negative effects on the mean diameter of the particles, thus indicating that increased amounts of this wall component

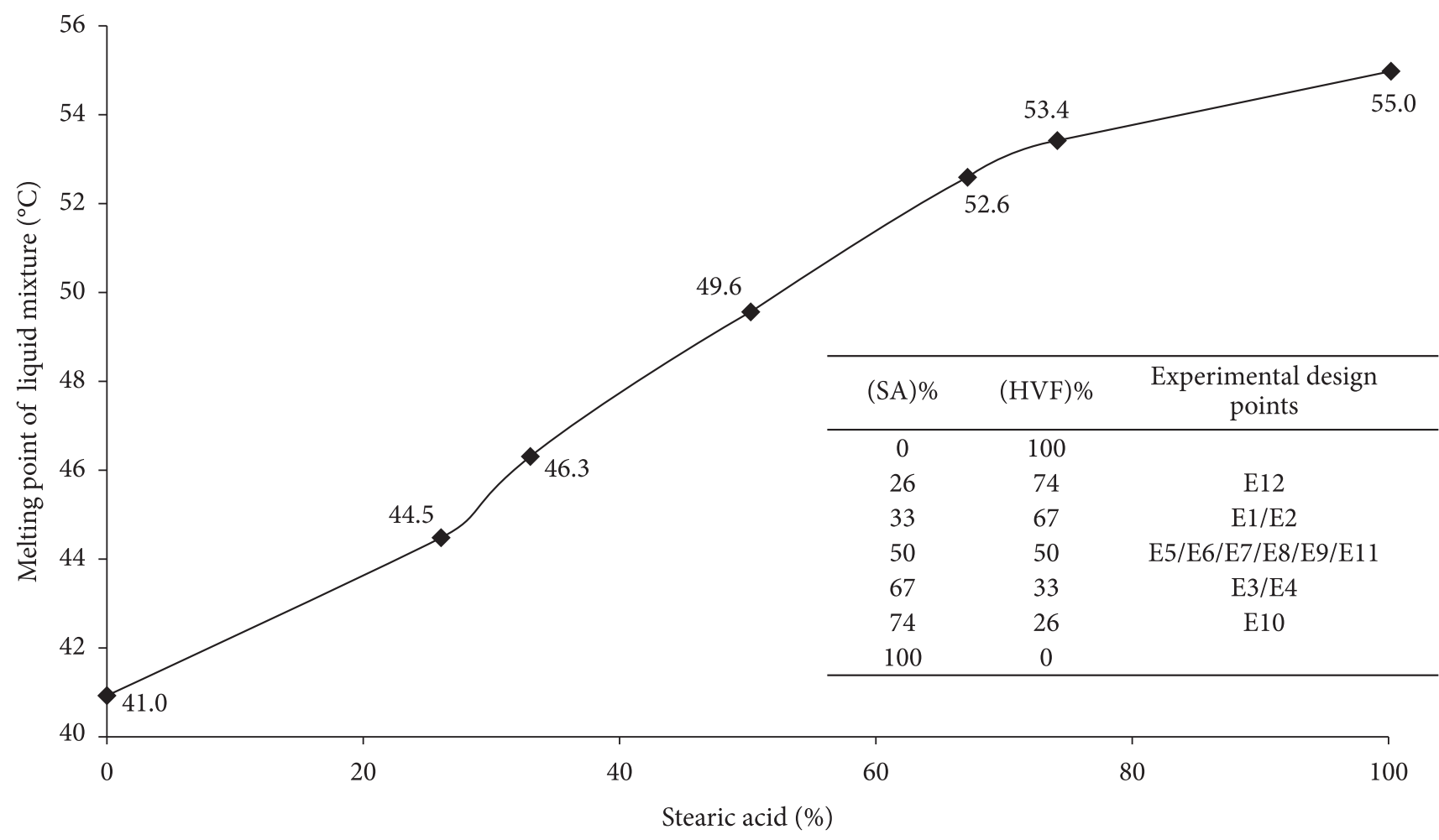

Figure 2. Melting point of lipid mixtures used as wall material for SLP production containing different amounts of stearic acid (SA). The letter E followed by a number refers to the experimental design runs. 
Table 2. Mean size $(\mu \mathrm{m})$ of lipid microparticles containing phytosterols (SLM) produced in the experimental design.

\begin{tabular}{|c|c|c|c|}
\hline \multirow{2}{*}{ Experiment } & \multicolumn{2}{|c|}{ Real/coded variables } & \multirow{2}{*}{$\begin{array}{c}\text { Mean } \\
\text { diameter }(\mu \mathrm{m}\end{array}$} \\
\hline & $\mathrm{PT}(\%)^{1}$ & SA $(\%)^{2}$ & \\
\hline 1 & $10(-1)$ & $33(-1)$ & 26.7 \\
\hline 2 & $30(1)$ & $33(-1)$ & 29.9 \\
\hline 3 & $10(-1)$ & $67(+1)$ & 17.2 \\
\hline 4 & $30(+1)$ & $67(+1)$ & 16.4 \\
\hline 5 & $20(0)$ & $50(0)$ & 16.3 \\
\hline 6 & $20(0)$ & $50(0)$ & 20.1 \\
\hline 7 & $20(0)$ & $50(0)$ & 19.5 \\
\hline 8 & $20(0)$ & $50(0)$ & 20.0 \\
\hline 9 & $6(-1.41)$ & $50(0)$ & 17.4 \\
\hline 10 & $20(0)$ & $74(+1.41)$ & 13.8 \\
\hline 11 & $34(+1.41)$ & $50(0)$ & 32.2 \\
\hline 12 & $20(0)$ & $26(-1.41)$ & 19.6 \\
\hline
\end{tabular}

${ }^{1}$ Phytosterols (core material); ${ }^{2}$ Stearic acid content on lipid mixture.
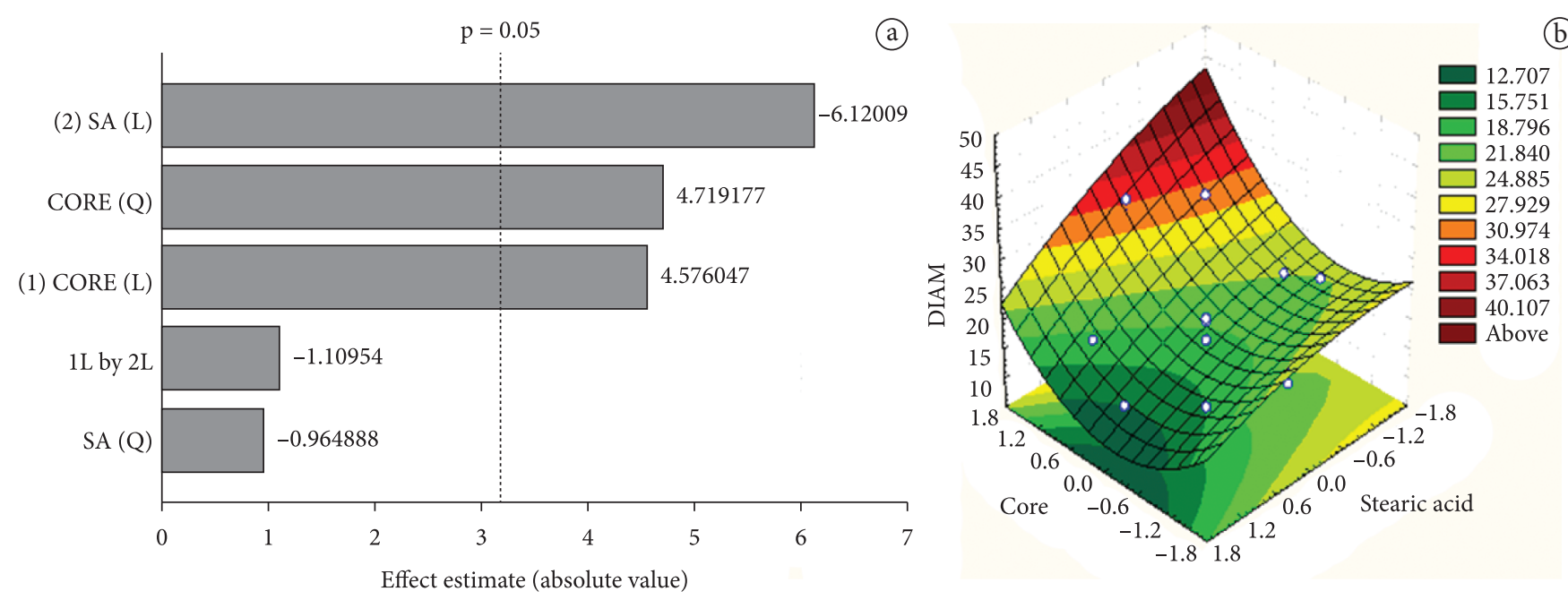

Figure 3. Effect of stearic acid (wall component) and phytosterol (core material) contents on the mean diameter of SLM produced by the spray chilling method. a) Pareto Chart; b) Surface Response.

resulted in diameter reduction $(\mathrm{p}<0.05)$. Variable amounts of phytosterols exhibited positive effects, thus indicating that increased amounts of this active substance resulted in an increase in the mean diameter $(\mathrm{p}<0.05)$.

In practical terms, these results indicate that matrices with low melting points tend to form lipid microparticles with larger mean diameters compared with matrices with high melting points. The melting points of the lipid matrices increased with the increase in the amount of stearic acid (Figure 2). In addition, the physical appearance of phytosterols at room temperature was pasty, indicating that this material had a low melting point. Consistent with this observation, the addition of phytosterols to the lipid mixture might have reduced the final melting point, thus leading to its positive effect on the mean diameter of the microparticles. The response surface in Figure $3 \mathrm{~b}$ corroborates the Pareto chart remarks since it shows that the area with largest diameters is the one closest to the condition of lesser amounts of stearic acid and the highest amount of phytosterols, which corresponds to the area with lower melting point lipid microparticles.

Ribeiro, Barrera-Arellano and Grosso (2012) found that increased additions of oleic acid to a lipid matrix of stearic acid with consequent reductions in the final melting points of the mixtures resulted in samples of lipid microparticles with increasing mean diameters.

Figure $4 \mathrm{a}, \mathrm{b}$ shows the appearance of the resulting lipid microparticles, which exhibited spherical shape and typical polydispersity of atomized products (THIES, 1995; RÉ, 1998). Such variation in diameters can also be observed in the size distribution shown in Figure 5. Chambi et al. (2008), Leonel et al. (2010) and Ribeiro, Barrera-Arellano and Grosso (2012) found similar appearance of lipid microparticles encapsulating proteins and sugars as active substances. 

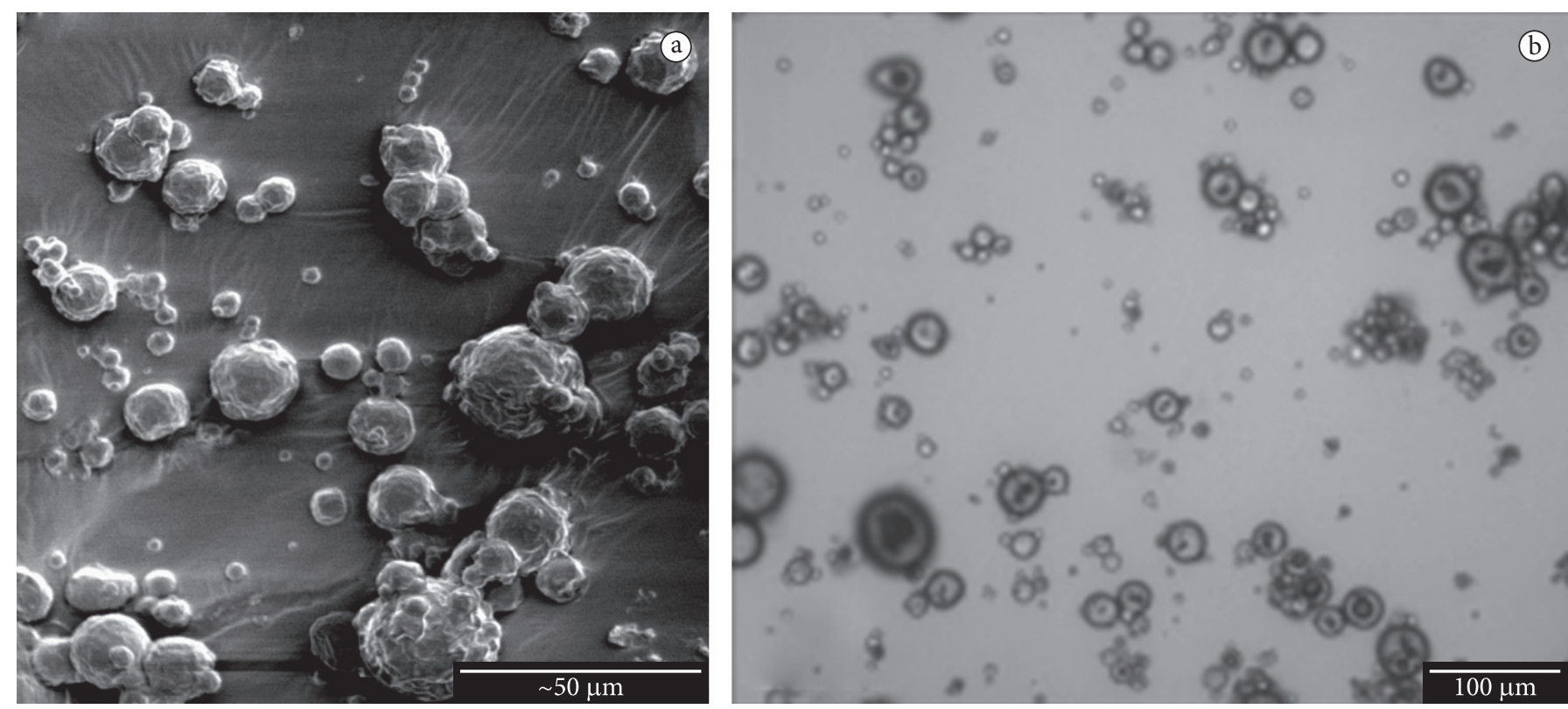

Figure 4. Micrographies of SLM containing phytosterol: a) scanning electron microscopy (500×, $50 \mu \mathrm{m}$ bar); b) optical microscopy (200×, $100 \mu \mathrm{m}$ bar).

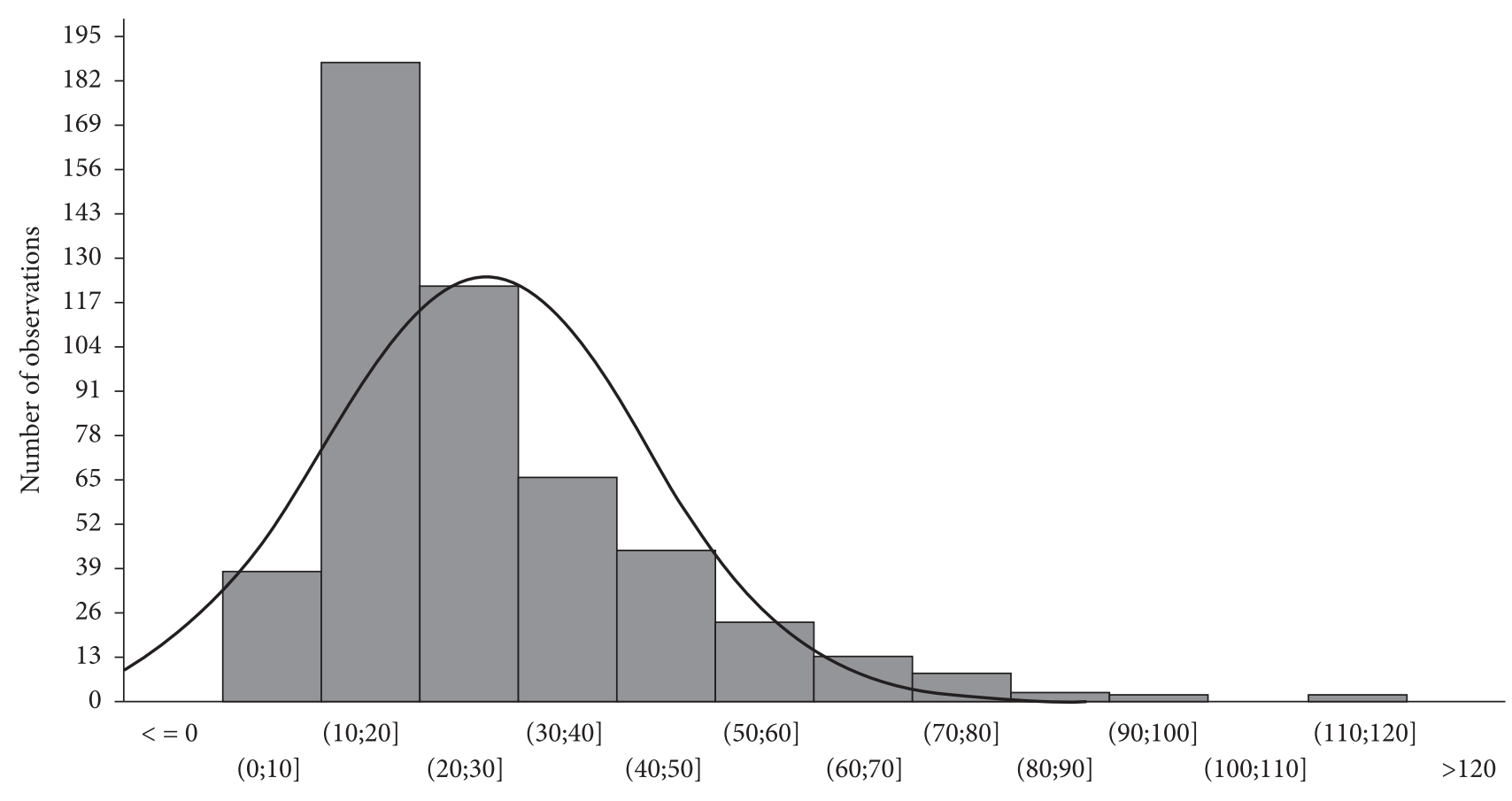

Diameter (micrometers)

Figure 5. Size distribution of SLM containing phystoterol (Experiment 1 of experimental design - Table 2).

\section{Conclusions}

Solid lipid microparticles containing phytosterols as a core material were successfully produced using the spray chilling technique and exhibited mean diameters within the range described in the literature. Increased amounts of stearic acid reduced the mean diameter, whereas increased amounts of phytosterols increased the mean diameter, thus indicating that softer matrices tend to produce larger microparticles. The samples exhibited the characteristic appearance of atomized products. From a handling, yield, and agglomeration point of view, lipid microparticles with higher melting point (i.e. more stearic acid and less core material contents) proved promising as a delivery system for hydrophobic substances, such as phytosterol, compared with that of lipid microparticles with lower melting points. 


\section{Acknowledgements}

The authors are grateful for the financial support provided by São Paulo Research Foundation (FAPESP), which made possible the development of this study (FAPESP 2009/107240, FAPESP 2010/09885-7, FAPESP 2011/11131-3 and FAPESP 2011/23442-3).

\section{References}

ALVIM, I. D.; GROSSO, C. R. F. Microparticles obtained by complex coacervation: influence of the type of reticulation and the drying process on the release of the core material. Ciência e Tecnologia de Alimentos, v. 30, n. 4, p. 1069-1076, 2010. http://dx.doi.org/10.1590/ S0101-20612010000400036

AMERICAN OIL CHEMISTS' SOCIETY - AOCS. The Official Methods and Recommended Practices of American Oil Chemists' Society. 5th ed. Champaign: AOCS Press, 2005.

BRASIL Food Trends 2020. Fatores que influenciam o consumo de alimentos. São Paulo: FIESP; Campinas: ITAL, 2010. cap. 4, p. 49-61. Disponível em: <http://www.brasilfoodtrends.com.br/>. Acesso em: 12 mar. 2012.

BRUFAU, G.; CANELA, M. A.; RAFECAS, M. Phytosterols: physiologic and metabolic aspects related to cholesterol-lowering properties. Nutrition Research, v. 28, n. 4, p. 217-225, 2008. PMid:19083411. http://dx.doi.org/10.1016/j.nutres.2008.02.003

CERCACI, L. et al. Phytosterol oxidation in oil-in-water emulsions and bulk oil. Food Chemistry, v. 102, n. 1, p. 161-167, 2007. http:// dx.doi.org/10.1016/j.foodchem.2006.05.010

CHAMBI, H. et al. Solid lipid microparticles containing water-soluble compounds of different molecular mass: Production, characterization and release profiles. Food Research International, v. 41, n. 3, p. 229-236, 2008. http://dx.doi.org/10.1016/j.foodres.2007.11.012

HOVENKAMP, E. et al. Biological effects of oxidized phytosterols: A review of the current knowledge. Progress in Lipid Research, v. 47, n. 1, p. 37-49, 2008. PMid:18022398. http://dx.doi.org/10.1016/j. plipres.2007.10.001

ILIĆ, I. et al. Microparticle size control and glimepiride microencapsulation using spray congealing technology.
International Journal of Pharmaceutics, v. 381, n. 2, p. 176-83, 2009. PMid:19446625. http://dx.doi.org/10.1016/j.ijpharm.2009.05.011

JONES, P. J. et al. Phytosterols in low- and nonfat beverages as part of a controlled diet fail to lower plasma lipid levels. Journal of Lipid Research, v. 44, n. 9, p. 1713-1719, 2003. PMid:12730296. http:// dx.doi.org/10.1194/jlr.M300089-JLR200

LEONEL, A. J. et al. Production and characterization of lipid microparticles produced by spray cooling encapsulating a low molar mass hydrophilic compound. Ciência e Tecnologia de Alimentos, v. 30, n. 1, p. 276-281, 2010. http://dx.doi.org/10.1590/ S0101-20612010005000014

KRITCHEVSKY, D.; CHEN, S. C. Phytosterols-health benefits and potential concerns: a review. Nutrition Research, v. 25, n. 5, p. 413-428, 2005. http://dx.doi.org/10.1016/j.nutres.2005.02.003

PASSERINI, N. et al. Evaluation of solid lipid microparticles produced by spray congealing for topical application of econazole nitrate. Journal of Pharmacy and Pharmacology, v. 61, p. 559-567, 2009. PMid:19405993. http://dx.doi.org/10.1211/jpp.61.05.0003

PIMENTA, A. et al. Guia Temático: Fitosteróis. 2009. Disponível em: $<$ http://www.saberfuncionais.com/docs/fitosterois_guia_final.pdf $>$. Acesso em: 20 jun. 2009.

RÉ, M. I. Microencapsulation by Spray-drying. Drying Technology, v. 16, n. 6, p. 1195-1236, 1998. http://dx.doi. org/10.1080/07373939808917460

RIBEIRO, M. D. M. M.; BARRERA-ARELLANO, D.; GROSSO, C. R. F. The effect of adding oleic acid in the production of stearic acid lipid microparticles with a hydrophilic core by a spray-cooling process. Food Research International, v. 47, n. 1, p. 38-44, 2012. http://dx.doi.org/10.1016/j.foodres.2012.01.007

SAVOLAINEN, M. et al. Evaluation of controlled-release polar lipid microparticles. International Journal of Pharmaceutics, v. 244 , n. 1-2, p. 151-161, 2002. http://dx.doi.org/10.1016/S03785173(02)00325-3

THIES, C. (Ed.). How to make Microcapsules - Lecture and Laboratory Manual. Sant Louis, 1995. chap. 5, p. 1-43.

WEINGÄRTNER, O.; BÖHM, M.; LAUFS, U. Controversial role of plant sterol esters in the management of hypercholesterolaemia. European Heart Journal, v. 30, n. 4, p. 404-409, 2009. PMid:19158117 PMCid:2642922. http://dx.doi.org/10.1093/eurheartj/ehn580 